\title{
Athena's legacy: Preparing women for a mentoring program
}

\section{Jennifer Boddy, Kylie Agllias, Mel Gray, Jill Gibbons}

\begin{abstract}
A community based research study conducted in 2004 identified a number of women from disadvantaged communities who sought mentoring in personal, educational, and vocational aspects of their lives. Informed by this earlier research, a program titled Map Your Future was developed and a pilot mentoring program commenced in 2005. This paper describes the group program that was developed to prepare the women for a mentoring relationship, and the research methodology underpinning its development. It concludes with an exploration of the women's experiences of the program.
\end{abstract}

Key words: Mentoring, women, group work, community.

According to the ancient Greece myth, Odysseus entrusted Mentor to provide guidance to his son, Telemachus, while he was away at the Trojan War. Athena, "the virgin goddess of arts, craft and war” is cited as assuming Mentor's form on numerous occasions to hide from unwanted suitors or to give advice to Telemachus (Tripp, 1970). While Athena's wise counsel of many young men has been widely acknowledged (Guerber, 1965; Tripp, 1970), some claim that Athena and Mentor are one and the same (Stalker, 1994). Indeed, Hansman's (2002) reading of Homer suggests that Odysseus asked the wise Athena to take the male form of Mentor in his absence.

Although the original mentor may have been a woman, modern day mentoring appears to have developed as a predominantly male phenomenon. Phrases such as "the network," "master and apprentice,” and “the old boys’ club,” have been associated with mentoring wherein more experienced men have helped younger ones to "learn the ropes". 
While interest in mentoring has been evident since the 1970s (Ellinger, 2002), most early research was concerned with mentoring for white upper-middle class males in business environments (see for example, Levinson, 1978). Historically, men have frequently had more access to mentoring than women (Braun, 1990; Hansman, 2002; Knouse, 2001), despite assertions that women experience greater barriers to career advancement than men (Ragins, 1999; Ragins \& Scandura, 1997; Tharenou, 2005). More recently, however, formalised mentoring programs have become increasingly linked to affirmative action for women and minorities within the workplace (Van Collie, 1998; Wadsworth, 2002).

Mentoring may not only be beneficial to those in the workplace, but also for women in the community seeking further education or gainful employment. This is because mentoring aims to be a supportive relationship, where the mentor, like the Goddess Athena, shares his or her knowledge and experience in order to assist with the personal and professional development of the mentee.

While mentoring should be based on an understanding of the needs and goals of the mentee, as well as mutual trust, care and concern (Gardiner, Grogan, \& Enomoto, 2000), it is not without its potential problems. At worst, a mentoring relationship can be abusive; the mentor may not share his or her knowledge openly; an unhelpful status quo may be promoted and the mentee may be exploited. There may be disagreement about goals, and behaviours adopted that encourage dependency rather than self-reliance (Eby \& Allen, 2002; Garvey \& Garrett-Harris, 2005; McDonald \& Hite, 2005; Moberg \& Velasquez, 2004). Programs designed to prepare participants for mentoring might mitigate some of the potential difficulties (Conway, 1998; Garvey \& Garrett-Harris, 2005).

A study conducted by final year social work students at the University of Newcastle Australia, in 2004, highlighted the views of the women being targeted for this program (Gibbons \& Gray, 2004). The findings indicated that participants had experienced many obstacles to achieving their personal goals: they had limited access to child care, onerous 
family obligations, low self-esteem, and chronic illness or injury (personally and within the family). A number of the participants felt guilty about pursuing their personal goals away from their primary caring role. Some said that their families had little understanding of their personal goals or needs, and some recounted a history of family or domestic violence which had affected their ability to pursue their goals (Gibbons \& Gray, 2004).

Results from this research were relayed to participants at a feedback forum where they decided that a group program would be beneficial in preparing themselves to be mentored. Through discussions at this forum it became apparent that many of the women saw themselves as both mentors and mentees, while others saw themselves only in the role of mentor, unable to see the value of it. Many of the women who were interested in being mentored did not have clearly articulated goals.

Thus a group program aimed at preparing women to be mentored was thought to be necessary. It would minimise the risks associated with mentoring relationships. It would assist the women in gaining clarity regarding the role/s they would like to undertake as mentors or mentees, and it would be useful in helping the women identify and develop their goals and skills in preparation for being mentored. In addition, for women from disadvantaged communities, a supportive program to build confidence and self-esteem could overcome barriers and create opportunities for personal and social development (Benevolent Society, 1999; S. G. Brown \& Barbosa, 2001).

Thus a preparation-for-mentoring group program began in 2005 comprising eight monthly sessions with 18 participants. This program formed part of an intervention research study conducted by social work researchers at the University of Newcastle, in New South Wales (NSW), in partnership with the facilitator of a school based community centre and a community development worker from the NSW Department of Housing.

The program was underpinned by a feminist perspective and a strengths approach as it was considered that these approaches would be helpful in understanding the situations 
of the women to be mentored and in preparing them for mentoring. A feminist perspective could provide insight into the women's subjective experiences (Stacey, 1997; Wearing, 1996) in light of the unequal power relationships and structural barriers that women from low socioeconomic backgrounds experience (Dominelli \& McLeod, 1989). It meant focusing on the women as individuals rather than on their roles as mothers and carers (Orme, 1998), and involved exploring their aspirations outside of their "traditional” roles. This approach focused on giving the "women a voice" and allowing their opinions to be heard (Gilligan, 1982; Weick, 2000). An empowering strengths based approach to program development was used to herald a move away from deficits-based foci on their oppression and powerlessness. This meant drawing on their knowledge and experience, their resilience in overcoming obstacles, and their strengths, abilities, resources, hopes, and values (Saleebey, 2006). This was a new experience for the women who were part of a culture where education and work opportunities were not seen as priorities and where emphasis was often placed on their role in the home.

Social group work was employed to prepare women for the mentoring relationship. The perceived advantages of such an approach included the development of a sense of belonging, greater control, and increased self-worth (Hoover, 2005). It was hoped that participants would gain a sense of belonging when their presence in the group was welcomed and they felt a sense of mutual understanding or acceptance. It was thought that the camaraderie of group decision making would offer relief from individual burdens of responsibility and opportunities to collectively brainstorm solutions (Hoover, 2005). A sense of belonging could also lead to psychological support networks enduring long after the group has ended. Social group work, together with an experiential learning model underpinned by constructivist theory, would also provide considerable opportunities for participants to lead the learning and group process. Each woman's individual experience, knowledge, and meaning construction was valued and participants were able to make their 
own decisions within the group, making them more likely to take ownership of, and responsibility for, their contributions and roles (Hoover, 2005). Thus participants were invited to reflect on their experiences within the group and to consider how they might apply their new learning to their future mentoring relationships.

\section{Methodology}

The research methodology which guided the development of the preparation-formentoring group program was an intervention research approach. Intervention research is a methodology used in the design and development of "human service technologies," such as social interventions or policies, that seek to improve community life and individual health and wellbeing (Fawcett et al., 1994; Rothman \& Thomas, 1994). It has three phases. The first involves acquiring knowledge about an issue, the second converting the information into a useable form by relating it to a practical application, and the third is concerned with the design, implementation, and evaluation of an intervention. This paper presents some of the preliminary findings from the third phase.

A major focus of the study was to involve the women in its design, implementation, and evaluation. Involving participants in decision making about the research and intervention process is empowering and transforming, and promotes the development of sustainable community-based interventions (Hart \& Bond, 1995; Hills \& Mullet, 2000; Walker \& Haslett, 2002). Time was allocated in each group session to check in with participants' experiences of the program and to elicit their feedback and ideas for the project. Further, between each group the facilitator and researcher met with the industry reference group to canvass issues and ideas for the program as it developed. 


\section{Program themes and content}

The five interconnected themes in the group program emerged from the initial research (including the literature review), ongoing consultation with the women in the groups, and consultation with academics and industry partners. They were:

1. Self-esteem and self-care - which included identifying and building on strengths, conducting a skills audit, developing coping strategies, and building support networks.

2. Examining hopes, dreams, and future aspirations - by revisiting hopes and dreams from the past, exploring options outside of women's traditional roles, opening up new areas of potential, and defining new hopes and dreams.

3. Teamwork - developing skills in working with others in a group, and enhancing communication skills.

4. Goal setting - by defining and setting priorities and mapping goals, and by preparing practically for the chosen activities (such as applying for a job or course).

5 Mentoring - involved looking at research about mentoring, considering the role of mentor and mentee, identifying how to benefit from the mentoring relationship, and defining what the women wanted from the mentoring relationship.

\section{Data collection and analysis}

Data collection procedures were determined by the aims of the study and the intervention research model used. It entailed collection of:

1. Demographic data regarding age, family structure, level of education, health and occupation and scales that measured self-esteem, optimism, ego resiliency and perceived social support.

2. Semi-structured interviews with schedules drafted from the aims of the project and the literature on mentoring programs. 
3. Researcher observations, notes and reflections which were recorded during the program using an ethnographic journal as a reflective tool.

4. Input from participants during the group sessions.

Multiple methods and data sources (triangulation) were used to develop a rich understanding of the group work process and to reduce researcher bias so as to increase the reliability and validity of the study. The approach to data analysis used has been described as the "hermeneutic circle" (Patton, 2002 p. 497). In striving for meaning, the hermeneutic circle requires moving between the parts and the whole in a constantly reflective process, taking the context of the study and the cultural lens of researchers and participants into account.

Using the meeting topic guide and the transcripts, open coding that identified the primary patterns in the data occurred. Coding qualitative data included sifting through the data, making sense of it, looking for patterns as well as exceptions, and categorising it analytically so that it was informative to the aims and objectives of the research (Darlington \& Scott, 2002). N-Vivo computer software was used to do this. Categories identified related to diversity and commonality among group members, goals and hopes, gender inequality, personal growth, self-care, and expectations for the group program and individual mentoring. These categories highlighted the factors important to a mentoring group work program and to the women's future mentoring relationships. Creating a safe environment, sharing common experiences, and working constructively with diversity were shown to be important to the group's success. The themes also demonstrated the significant challenges that the women faced when trying to work in a group to change their circumstances, as social structures and ideologies that maintain gender inequality in their lives were particularly evident. In reporting on these findings, the authors are describing the particular experiences of a group of women from disadvantaged backgrounds and make no claims as to the generalisability of these findings.

Page 7 of 24 


\section{Findings and discussion}

Eighteen women commenced the preparatory program and thirteen completed it. Of those who withdrew, one moved to another city, two had work commitments (one in a voluntary capacity and one in a paid capacity), one withdrew for health reasons, and another reported that the time between sessions (one month) was too long and she was no longer motivated to stay involved. Participants all withdrew in the first half of the group program. Women ranged in age from 21 to 62 . The mean age was 37 and the median age was 36. Sixteen of the women had children, eight had partners, two had some form of paid employment, and seventeen were engaged in voluntary work. With regard to education, thirteen participants had completed the Year 10 School Certificate and three participants had left before this point (in Year 9). One woman had completed the Higher School Certificate (Year 12) and one had completed tertiary study in later life.

Participants were located across four suburbs. Drawing on 2001 and, where attainable, 2006 census data (Australian Bureau of Statistics, 2001;, 2006) it became apparent that the suburbs from which the women were recruited, experienced considerable disadvantage compared with the state of New South Wales. In each of the suburbs, the median weekly household income was well below the state average. Unemployment was significantly higher in all suburbs and one parent families were more common. Completion of high school was below the state average and in one suburb only $10 \%$ of the population completed secondary school in contrast to the state average of $42 \%$.

During the group program it emerged that all participants had stories of considerable adversity and most of the participants had grown up in families where mental illness, abuse, and drug and alcohol addiction were present. Of the women who did share their experiences, their considerable strength in surviving and overcoming obstacles in their lives was particularly evident.

Page 8 of 24 


\section{Learning requires a safe environment}

Behavioural change is not solely motivated by the introduction of new knowledge or personal reflection. It requires a critical exploration of existing knowledge, the introduction of new information, as well as a place to build theory, test action, and reflect on experience (Johnson \& Johnson, 2006). The utility of experiential learning then, is that it aims to “alter the learner's cognitive structures, modify the learner's attitudes, and expand the learner's repertoire of behavioral skills” (Johnson \& Johnson, 2006 p. 48). Skills learnt and practised in the group were directly transferable to the participant's environment, as one participant, Jodie, stated, “Because I’ve been learning to speak out at the mentoring program I'm learning to speak out in other places.”

Safety is the key element to an experiential learning environment, where participants are encouraged to try out new and often challenging experiences. Safety in a group is often associated with the notion of trust, and having a confidence or belief in the integrity and character of other group members, the facilitator and of the group process itself. Trust is often reliant on inconclusive evidence, so the facilitator must create an environment in which all women are treated with dignity and respect, providing consistent examples of their trustworthiness.

In the preparation-for-mentoring program, tolerance of opposing viewpoints and a space where the women felt free to speak up was sought from the formative stage. A group agreement was developed by the women that specified their collective safety requirements and this was referred to at different stages of the group development. Key agreements included "participation is voluntary," "everyone has their own opinion” and “there are no right or wrong answers." The women acknowledged that safety was a necessary element in encouraging experimentation with new behaviours. Tina commented: 
I don't have a very high self-esteem and I never sort of spoke up at all and it's not like other people walk all over me or anything, I've just never really said much. I still worry about what other people think, but with these sessions and stuff nobody's going to laugh at you and nobody's going to ridicule you, and I've been giving my opinion a bit more when normally I'd sit back and go with the group. I'm sort of speaking up and saying 'Well this is my opinion and I think we should do this,' which is good for me.

Self-determination is central to both feminist and social group work principles and it also underpins group safety. In the preparation program, participants were invited to engage in a manner that they were comfortable with. A range of activities was offered to highlight the various strengths of the women in the group (see Table 1 Theme 4 for an example), and the facilitator tried to balance encouragement with covert expectations of participation. At times this was extremely difficult, with the facilitator needing to remain cognisant of power differentials and the personal expectations of the group. Wherever possible the sessions and exercises were client-paced. Evaluation was a continual process, where the facilitator and researcher checked in with women as to the relevance and usefulness of various activities. Additionally women were encouraged to voice their desires and needs for upcoming sessions and their ideas were incorporated into group program development. Within this safe, encouraging and accepting environment, the women felt free to express previously hidden concerns. As Leanne commented, “I can go there and I'm not embarrassed about the situation that I'm in and in normal everyday channels I wouldn't be able to share all this information.” Others, like Corrine, experienced shifts in their self-confidence, saying, "I’ve noticed a few changes [in myself] 
and I feel like I've grown up a bit, I'm a bit more mature and I feel like I can express my feelings a bit better.”

\section{Learning requires shared experiences}

“To be without membership is to be alienated, to be at risk of marginalisation, and oppression” (Saleebey, 2006 p. 12). Women in disadvantaged communities are often isolated both physically and emotionally. Without different perspectives or encouragement to experiment with new ideas, women may explain their negative experiences in terms of their own inadequacies and these beliefs may become entrenched (Butler \& Wintram, 1991). Thus the process of empowerment requires more than the development of self-esteem and self-efficacy. It must be supported by a growing understanding of self in relation to others. For this reason, teamwork exercises were frequently incorporated into the preparation program, and women were encouraged to examine differing values, beliefs, and opinions (see Table 1, Theme 3, for an example).

A group can be an effective strategy in the shared witnessing of the women's stories; it offers them the knowledge that they are not alone and that they may have experiences similar to those of others (Carey, 1999). When reflecting on the formative stages of the preparation-for-mentoring sessions, Sara said, "It's good to see that other women have been through the same thing and are trying to find where they belong.”

The realization of commonality reduced feelings of inadequacy, guilt, isolation, sadness, and shame, that is, feelings that often result when people think that they are the only ones who are experiencing a particular problem. As the women started to empathise with the lives of others, they made comments such as the following, "Just the interaction with other women that are in similar situations and seeing them all grow has helped me grow” (Deanne). This is supported by Brown's (2006) research into shame resilience 
theory, which suggests that experiencing empathy from others mitigates the shame and powerlessness that women may experience. Saleebey (2006) states:

Humans can only come into being through a creative and emergent relationship with others. Without such transactions there can be no discovery and testing of one’s powers, no knowledge, no heightening of one’s awareness and internal strengths. In dialogue we confirm the importance of others and begin to heal the rift between self, other and institution. (p.14)

Characteristic of the "maturation" or "performing" phase of group work, the women in the preparation program moved from witnessing and empathising to assisting each other to problem solve, and affirming each other's decisions. Many exercises were completed in teams or pairs to maximize collective knowledge and strengths and afford the women opportunities to increase awareness of their interpersonal problem solving styles in preparation for the mentoring relationship. As Linda commented, "I think if I didn't have the other ladies to talk to, I don't think I would have kept going. All the other ladies have got similar problems to what I've got and we can work it out all together.”

\section{The challenge of difference}

Facilitating a group with diverse membership can be both challenging and rewarding. The women in this program articulated their differences in a number of ways, sometimes striving for recognition of their diversity and sometimes seeking a means of harnessing power within the group. Johnson and Johnson (2006) identify three main areas of diversity in groups: demographic, personal characteristics, and abilities and skills. The participants in this group came from four similar but distinct locations. They varied in age, and marital and parental status. They held a range of values and beliefs, and had different 
life experiences, hopes, and skills. Over the course of the group, the facilitator acknowledged diversity, modelled respect for difference, and encouraged a demystification of stereotypes though group process. The areas of age and location appeared to be the biggest challenges to group cohesion. Wayne and Gitterman (2003) claim that:

Members enter into groups with feelings of both hopefulness that they will benefit from the new experience and concern that they could, in some way, be hurt within the group. They enter with caution and with the defences they typically use in the face of social situations with many unknowns. (p.33)

For some women the attributes of maturity and experience, often respected in their own communities, may have acted as an initial source of diversion in this group. In some cases, their "responsible elder" status supported women to focus on the growth and development of the younger members of the group, to the detriment of their own. This was demonstrated when Cassandra was asked about what she saw as the benefits of the program and she replied by considering the benefits for the younger participants stating, "I just felt that a lot of girls who were coming along did not have such hope in themselves. And now they seem to be glowing.” This needed to be challenged on both a psychological and social level, inviting women to examine the power imbalance these dynamics maintained within the group and to critique the societal constructs that positioned young women’s learning above mature women's growth.

Women also entered the group identifying with their suburb and the reputation or mythology surrounding it. Camancho (2001) says that "members who identify strongly with a subgroup may feel in the minority in spite of being a part of the group's majority,” (p.137) and this was certainly the case for some women in this group. Experiences of 
stigmatisation and disadvantage associated with coming from a particular suburb were played out in the group. Sometimes the women's experience of these inequalities was replicated, at other times women's responses seemed to be instinctively attuned to their historical responses to being stereotyped. For example, Helen was being challenged about her views on parenting when she responded, “Doesn't mean people can shit on us just because we're from Smith Town ${ }^{1}$...” Her response indicates that she felt she was being treated with disrespect due to the suburb she lived in, and highlights the inequalities and stereotypes that persistently challenge women from localities perceived as disadvantaged.

Working with women from disadvantaged backgrounds requires a shift from seeing participants as "victims" to seeing them as agents challenging discriminatory arrangements (Krumer-Nevo, 2005). In this group conflicts about diversity were viewed as opportunities to hone skills in critical thinking, negotiation, and assertiveness. At other times, issues needed to be addressed retroactively and future sessions and exercises were tailored to challenge thinking about areas of conflict raised by the women. The use of strengths exercises served to highlight the individual capacities of women and to challenge some of the fundamental attribution error that may have existed within the group.

\section{The challenge of gender}

Women taking power means that time is often spent in deliberating about the old order and engaging in the excitement and apprehension of the new. It is readily understandable if women opted to remain in familiar environments - even oppressive ones - aware of what they were doing (Butler \& Wintram, 1998). While the women who

\footnotetext{
${ }^{1}$ Pseudonym for actual suburb
}

Page 14 of 24 
remained in this group chose not to stay with the familiar, it is important not to minimise the effort and courage it takes to stand against a resistant old order. Gillian explained, "It's always: 'Why do you want to do that, you can’t be successful, you're not good enough,' and I've copped that through ... and it's still there.”

Many of the skills and talents that women possess are expressed and developed in the family and voluntary spheres (Baxter, 2002; Carlin, 2001), and this was particularly evident with many of the women who attended the group sessions. Through discussion and exercises the women were encouraged to share what they had wanted to be at an earlier stage in their life with the aim of rekindling the passion of past desires (see Table 1, Theme 2 for an example). Some of the women had ideas about work and career in childhood without having much inclination of what this might be. As they grew older, their choices seemed to become more about what was available to them (e.g. retail), what they were already doing (e.g. child carer or mother) or what felt fun (e.g. cutting brother's hair). Many dreams stopped abruptly when the reality of the world hit home including unplanned pregnancy, the need for money, and relationships that promoted "mothering" as a career. Two of the women said they did not want to have children but this was expected of them if they went into a relationship and this is what they did.

Many of the women expressed awareness around the gender inequalities they experienced. In the first group session a film was played which showed the advertisement Rinso laundry powder: Hilda and Hugh Jones (c1940) (Leonard, 1996). This film showed a traditional married couple in their home, with the wife Hilda doing the washing and cooking while her husband, Hugh, went to work. This film was used as a discussion point to trigger critical examination of gender inequalities. Some of the women commented that such inequalities are still present today, while others, particularly younger women, challenged this idea. Leah, in her 20s, said that when this advertisement was filmed it was “expected [that the woman was] to be perfect and dandy when His Highness came home. 
Now it's reversed and [we] have to share responsibilities. Everyone is equal”. However, Justine and Amy, both in their 20s, had different experiences. Both Justine and Amy commented, "That used to be me.” Similarly Gillian thought that while there have been changes, some inequalities are still present. Lisa expressed a similar sentiment, stating:

[It's] not totally the case now but there are still instances where this is the case. Still live in a male dominant society. Don’t have [the] equality we deserve. We've got it, but it's not recognised. It is sad how far women go. I can feel like that lady.

This exercise enabled the women to begin critically examining gender stereotypes, particularly around women as carers and nurturers. It highlighted the shifts that women have made over time, while inviting the women to consider what they'd like to see happen in the future. Such discussion reminded the women they are capable change agents, and provided a foundation for thinking about their own needs and goals.

In another exercise where the women were asked to examine their hopes and dreams (see Table 1, Theme 2 for details), it became evident that some women had trouble thinking about career, employment, and education in terms of something that they would be good at or something that would be interesting. They found it difficult to identify their interests and then work them into their career plans. It was as though career were something one did for money rather than interest, pleasure, self-fulfilment, or a sense of accomplishment. As Corrine remarked, “I’ve never really done anything for myself, I’ve always just worked, got paid, and that's it." Additionally, a few women had trouble finding anything that they were interested in at all and some were clearly unaccustomed to expressing their likes and dislikes. All the women had started to make career plans by the end of the program. 
Despite their newfound interest in employment and a career, none wished to abandon their "caring" roles with some wanting to take this outside the family to jobs like nursing, midwifery, child care, and youth work; some were already working voluntarily, or had worked, in this field. The caring role was one they felt comfortable with due to their life experiences; they wanted to share their experience and believed that they had a level of empathy that others might not have having been raised in the school of hard knocks. For example, one participant who wanted to be a youth worker explained her interest as coming from her experiences in childhood and adolescence and wanting to "help" others in that situation. Another woman was interested in being a midwife and saw that her experience of motherhood would be valuable to this work. Additionally, almost all of the women in the program were participating in the voluntary sector, which suggested that this work provided them with a solid sense of wellbeing, belonging, and accomplishment. Many women's skills and talents were absorbed within the family and voluntary spheres, so there were sometimes tensions when women expanded their roles. As Gillian said, “They [mother, sister and relatives] don't know what I'm doing simply because if I was to tell them they would bring me down so far.”

Sometimes family and voluntary arenas also created barriers to participation in the preparation program. Dilemmas arose when the women had to choose between attendance at the MYF program or taking her child to the doctor, or between the MYF program and canteen duty at the local school. Because women are often "other" oriented it can be difficult for them to cater to their own needs. Gross (1998) proposed that when women subscribe to an intensive mothering ideology, "their sense of accomplishment in other spheres of their lives, such as work outside the home, is often undermined by chronic ambivalence about the morality of their choices and the adequacy of their mothering” (p.2). Because family and community identity is often the primary source of pride and satisfaction, it can be difficult to choose a potentially uncomfortable journey over a well- 
trodden path. Again these issues needed to be addressed within the group with a careful balance between self-determination and a feminist critique of gender imbalance.

\section{Conclusion}

Unlike the young men of Greece, the women in this research had not had access to the mentoring offered by Athena. Models of female mentoring in the community are rare. It was necessary to engage the skills and expertise of potential mentees in creating a program that was responsive to their particular needs. Consequently the program was developed in consultation with participants and drew on prior research conducted by final year social work students that emphasised the importance of preparing women to enter into mentoring relationships, to promote self-care, to minimise the risks of exploitation and to consider their hopes and dreams for the future. While group members initially requested monthly sessions, it became apparent to the program facilitator and researcher that more frequent sessions would assist with continuity. Group members agreed, and recommended future programs have sessions more frequently.

Findings from the evaluation of the preparation group demonstrated the importance for the women of connecting through shared experiences while respecting diversity, the value of safety and the empowerment of group members, and an understanding of the gendered roles that women participate in. The preparation-for-mentoring program was one stage in a larger research study. Following the group program, potential mentors were identified and trained using a similar model before being matched with the mentees who completed this stage of the program. The authors look forward to reporting on subsequent stages. 
Table 1: Examples of group work exercises

\begin{tabular}{|c|c|c|}
\hline Theme & Example of Exercise & Purpose of exercise \\
\hline $\begin{array}{l}\text { 1. Self-esteem } \\
\text { and self-care }\end{array}$ & $\begin{array}{l}\text { CHANGE EXERCISE. } \\
\text { Participants are asked to brainstorm the concept of } \\
\text { "change," allocating their responses to a column headed } \\
\text { either "risk" or "opportunity." Participants then engage in } \\
\text { discussion about the changes they have previously } \\
\text { experienced and those they may experience throughout } \\
\text { the program. Discussion might include planning for } \\
\text { change, assessing risk and benefit and the importance of } \\
\text { realistic self-care strategies. }\end{array}$ & $\begin{array}{l}\text { To explore the concept of change as a } \\
\text { manageable process. } \\
\text { To reiterate the importance of self-care } \\
\text { strategies in everyday life and in times of } \\
\text { change and growth. } \\
\text { To continue thought and discussion } \\
\text { regarding personal preparation for } \\
\text { upcoming challenges. }\end{array}$ \\
\hline $\begin{array}{l}\text { 2. Examining } \\
\text { hopes and } \\
\text { dreams for } \\
\text { future }\end{array}$ & $\begin{array}{l}\text { WHEN I GROW UP EXERCISE. } \\
\text { Participants are asked to sit quietly and think about their } \\
\text { first thoughts and ideas about being an adult with a job or } \\
\text { hobby or career. They are asked to remember the first time } \\
\text { they started to think about what they would be when they } \\
\text { grew up. Participants are then asked to either write or draw } \\
\text { this on a large piece of card. Participants are asked how } \\
\text { this idea might have changed over time and to map the } \\
\text { different ideas they have had about career. Some might } \\
\text { like to include the actual jobs they held over time as well. } \\
\text { Participants are encouraged to share their stories in the } \\
\text { large group. Discussion might include the influences on } \\
\text { career choice and themes and patterns in participant's } \\
\text { choices, as well as desires that have not yet come to } \\
\text { fruition. }\end{array}$ & $\begin{array}{l}\text { To explore the historical development of } \\
\text { ideas about self in relation to career and } \\
\text { education. } \\
\text { To view exploration and change as positive } \\
\text { and ongoing learning processes. } \\
\text { To expand the range of career/educational } \\
\text { possibilities for women. } \\
\text { To remember (and maybe recapture) some } \\
\text { of the excitement of dreaming about future } \\
\text { possibilities. } \\
\text { To acknowledge some of the past barriers } \\
\text { to change/success. } \\
\text { To trigger thoughts about how women } \\
\text { might prepare for upcoming challenges. }\end{array}$ \\
\hline 3. Team work & $\begin{array}{l}\text { A STORY OF TEAMWORK EXERCISE (adapted from } \\
\text { Rooth, 1995). } \\
\text { Cover a table with about sixty pictures cut from magazines. } \\
\text { Ask the women to browse, take their time to choose a } \\
\text { picture that they like or that interests them. Now divide the } \\
\text { women into groups of about five participants. }\end{array}$ & $\begin{array}{l}\text { Participants to develop confidence } \\
\text { speaking in small and large groups. } \\
\text { To develop communication skills } \\
\text { (particularly listening, negotiating and oral } \\
\text { presentation skills). } \\
\text { To tap into the creative skills of members of } \\
\text { the group. }\end{array}$ \\
\hline
\end{tabular}

Page 19 of 24 


\begin{tabular}{|c|c|c|}
\hline Theme & Example of Exercise & Purpose of exercise \\
\hline $\begin{array}{l}\text { 3. Team work } \\
\text { cont... }\end{array}$ & $\begin{array}{l}\text { Ask each member of the group to explain to the small } \\
\text { group why they chose this picture and then ask the group } \\
\text { to develop an imaginary story using all of these pictures. } \\
\text { All pictures must be included in the story and the story } \\
\text { must contain the words teamwork and communication in it. } \\
\text { After each small group shares their story with the large } \\
\text { group discussion ensues about the communication skills } \\
\text { demonstrated throughout the exercise. Participants are } \\
\text { also asked to think about any communication skills that will } \\
\text { be important for the future mentoring relationship. }\end{array}$ & $\begin{array}{l}\text { To encourage and develop teamwork skills } \\
\text { To encourage the recognition and naming } \\
\text { of particular communication skills. } \\
\text { To encourage reflection on teamwork roles } \\
\text { and skills. }\end{array}$ \\
\hline 4. Goal setting & $\begin{array}{l}\text { NOTICING AND CELEBRATING CHANGE } \\
\text { Participants spent a significant amount of time in the group } \\
\text { learning to set and map goals using the SMART (Specific, } \\
\text { Measurable, Attainable, Realistic, Timely) process. While } \\
\text { this is a very useful tool for women it is supported by } \\
\text { regular small exercises such as the following. At the end of } \\
\text { the group participants are asked to name one small goal } \\
\text { they have set for the upcoming month and how they might } \\
\text { feel if they accomplished this. They are encouraged to } \\
\text { identify the steps involved in achieving this and to discuss } \\
\text { this with the large group and adapt the goal if it may be } \\
\text { unrealistic. Members are then encouraged to share their } \\
\text { success or learning in the next session. The emphasis on } \\
\text { this sharing is not about the completion of the goal but the } \\
\text { learning from the experience. }\end{array}$ & $\begin{array}{l}\text { For women to practice goal setting } \\
\text { techniques. } \\
\text { For participants to continue noticing and } \\
\text { mapping their responses to challenge and } \\
\text { change. } \\
\text { For participants to learn about the } \\
\text { importance of planning in achieving goals. } \\
\text { To develop realistic goals. } \\
\text { To develop strategies to break larger goals } \\
\text { and visions into smaller more achievable } \\
\text { tasks to avoid becoming overwhelmed. }\end{array}$ \\
\hline 5. Mentoring & $\begin{array}{l}\text { SOMEONE I ADMIRE EXERCISE. } \\
\text { Participants are asked to think about a woman they } \\
\text { admire. This may be a friend, relative, historical figure or } \\
\text { personality. Each participant is asked to introduce the } \\
\text { woman to the group and name a few qualities that they } \\
\text { admire about this person. When all answers are listed, } \\
\text { participants discuss the qualities in terms of potential } \\
\text { mentors. Additional qualities may be added if necessary. } \\
\text { Women are then asked to develop a "Job Description" by } \\
\text { listing "essential" and "desirable" qualities and attributes } \\
\text { that they require of their potential mentor. }\end{array}$ & $\begin{array}{l}\text { To commence a discussion about the } \\
\text { desirable attributes of a mentor. } \\
\text { For participants to start thinking about and } \\
\text { listing the qualities that they would like in a } \\
\text { mentor. } \\
\text { For participants to start thinking about the } \\
\text { attributes they possess that may assist } \\
\text { them in mentoring others in the future. }\end{array}$ \\
\hline
\end{tabular}

Page 20 of 24 


\section{References}

Australian Bureau of Statistics. (2001). 2001 census community profile series: New South Wales. Retrieved 15 February, 2005, from www.abs.gov.au

Australian Bureau of Statistics. (2006). 2006 census community profile series: New South Wales. Retrieved 5 August, 2007, from www.censusdata.abs.gov.au

Baxter, J. (2002). Patterns of change and stability in the gender division of household labour in Australia, 1986-1997. Journal of Sociology, 38(4), 399-426.

Benevolent Society. (1999). Submission to the Commonwealth Government review of welfare. Retrieved 3 February, 2005, from http://www.bensoc.asn.au/research/review_welfare.html

Braun, R. (1990). The downside of mentoring. In L. B. Welch (Ed.), Women in higher education: Changes and challenges (pp. 191-198). New York: Praeger Publishers.

Brown, B. (2006). Shame resilience theory: A grounded study on women and shame. Families in Society, 87(1), 43-53.

Brown, S. G., \& Barbosa, G. (2001). Nothing is going to stop me now: Obstacles perceived by low-income women as they become self-sufficient. Public Health Nursing, 18(5), 364-372.

Butler, S., \& Wintram, C. (1991). Feminist groupwork. London: Sage Publications.

Camancho, S. F. (2001). Addressing conflict rooted in diversity: The role of the facilitator. Social Work with Groups, 24(3/4), 135-152.

Carey, M. (1999). Communities of shared experience. In C. White \& D. Denborough (Eds.), Extending narrative therapy: A collection of practice based papers. Adelaide: Dulwich Centre Publications.

Carlin, P. S. (2001). Evidence on the volunteer labor supply of married women. Southern Economic Journal, 4(67), 801-825.

Conway, C. (1998). Strategies for mentoring. Chichester: John Wiley \& Sons. 
Darlington, Y., \& Scott, D. (2002). Qualitative research in practice: Stories from the field. Crows Nest: Allen \& Unwin.

Dominelli, L., \& McLeod, E. (1989). Feminist social work. Houndsmills: Macmillan Education Ltd.

Eby, L. T., \& Allen, T. D. (2002). Further investigation of protégés' negative mentoring experiences: Patterns and outcomes. Group and Organization Management, 27(4), 456479.

Ellinger, A. D. (2002). Mentoring in contexts: the workplace and educational institutions. In C. A. Hansman (Ed.), Critical perspectives on mentoring: Trends and issues. Columbus: ERIC Clearinghouse on Adult, Career, and Vocational Education.

Fawcett, B., Suarez-Balcazar, Y., Balcazar, F., White, G., Paine, A., Blanchard, K., et al. (1994). Conducting intervention research: The design and development process. In J. Rothman \& E. Thomas (Eds.), Intervention research: Design and development for human research. New York: The Haworth Press.

Gardiner, M. E., Grogan, M., \& Enomoto, E. (2000). Coloring outside the lines: Mentoring women into school leadership. Albany: State University of New York Press.

Garvey, B., \& Garrett-Harris, R. (2005). The benefits of mentoring: A literature review. Sheffield: Report for East Mentors Forum, Mentoring and Coaching Research Unit, Sheffield Hallam University.

Gibbons, J., \& Gray, M. (2004). Map your future: A women's mentoring project. Retrieved 4 April, 2005, from http://www.newcastle.edu.au/centre/windale/Stage3Report.pdf Gilligan, D. (1982). In a different voice: Psychological theory and women's development. Cambridge, Mass.: Harvard University Press.

Gross, E. (1998). Motherhood in feminist theory. Affilia: Journal of Women and Social Work, 13(3), 269-273.

Guerber, H. A. (1965). The myths of Greece and Rome. London: George G. Harap and Co. Ltd. 
Hansman, C. A. (2002). Facing forward: Implications for practice and suggestions for future research (Information series No. 388). Columbus: ERIC Clearinghouse of Adult, Career and Vocational Education.

Hart, E., \& Bond, M. (1995). Action research for health and social care: A guide to practice. Buckingham, Philadelphia: Open University Press.

Hills, M., \& Mullet, J. (2000). Community-based research: Creating evidence-based practice for health and social change. Retrieved 11 March, 2004, from http://www.ed.gov/pubs/OR/ConsumerGuides/mentor.html

Hoover, J. F. (2005). Effective small group and team communication. Wadsworth, CA: Thompson.

Johnson, D. W., \& Johnson, F. P. (2006). Joining together: Group theory and group skills (9th ed.). Boston: Pearson.

Knouse, S. B. (2001). Virtual mentors: Mentoring on the Internet. Journal of Employment Counseling, 38(4), 162-169.

Krumer-Nevo, M. (2005). Reading a poor woman's life: issues and dilemmas. Affilia Journal of Women and Social Work, 20(1), 87-102.

Leonard, B. (Writer) (1996). Skeletons in our closet [videorecording]: When Australia was politically incorrect! Australia: National Film and Sound Archive.

Levinson, D. (1978). The seasons of a man's life. New York: Knopf.

McDonald, K. S., \& Hite, L. M. (2005). Ethical issues in mentoring: The role of HRD. Advances in Developing Human Resources, 7(4), 569-582.

Moberg, D. J., \& Velasquez, M. (2004). The ethics of mentoring. Business Ethics Quarterly, 14(1), 95-122.

Orme, J. (1998). Feminist social work. In R. Adams, L. Dominelli \& M. Payne (Eds.), Social work: Themes, issues and critical debates (pp. 218-228). Houndmills: Macmillan Press.

Patton, M. (2002). Qualitative research and evaluation methods (3rd ed.). Thousand Oaks, CA: Sage Publications. 
Ragins, B. R. (1999). Gender and mentoring relationships: A review and research agenda for the next decade. In G. N. Powell (Ed.), Handbook of gender and work (pp. 347-370). Thousand Oaks, CA: Sage Publications.

Ragins, B. R., \& Scandura, T. A. (1997). The way we were: Gender and the termination of mentoring relationships. Journal of Applied Psychology, 82(6), 945-953.

Rooth, E. (1995). Lifeskills: A resource book for facilitators. Manzini, Swaziland: Macmillan. Rothman, J., \& Thomas, E. J. (1994). Intervention research: Design and development for human service. New York: Haworth Press.

Saleebey, D. (2006). The strengths perspective in social work practice (4th ed.). Boston: Pearson.

Stacey, J. (1997). Feminist theory: Capital F, Capital T. In V. R. Robinson, D. (Ed.), Introducing Women's Studies (2nd ed.): Macmillan.

Stalker, J. (1994). In academe: Women mentoring women in the academy. International Journal of Lifelong Education, 13(5), 361-372.

Tharenou, P. (2005). Does mentor support increase women's career advancement more than men's? The differential effects of career and psychosocial support. Australian Journal of Management, 30(1), 77-109.

Tripp, E. (1970). The handbook of classical mythology. London: Arthur Baker Ltd.

Van Collie, C. (1998). Moving up through mentoring. Workforce, 77(3), 36-42.

Wadsworth, E. M. (2002). Giving much: Gaining more - mentoring for success. Indianna: Purdue University Press.

Walker, C. B., \& Haslett, T. (2002). Action research and systemic thinking (Working paper No. 15/02): Monash University, Faculty of Business and Economics.

Wayne, J., \& Gitterman, A. (2003). Offensive behavior in groups: Challenges and opportunities. Social Work with Groups, 26(2), 23-24.

Wearing, B. (1996). Gender: The pain and pleasure of difference. Melbourne: Longman.

Weick, A. (2000). Hidden voices. Social Work, 45(5), 395-402. 